\title{
RISK MANAGEMENT ACCORDING TO THE STUDIES AMONG EXPORTING MICROENTERPRISES FROM WESTERN POMERANIA
}

\section{HANNA SOROKA-POTRZEBNA}

\begin{abstract}
University of Szczecin, POLAND
e-mail: hanna.soroka@wzieu.pl

RECEIVED

25 January 2016

ACCEPTED

1 November 2016

JEL

CLASSIFICATION

G32, M20

KEYWORDS management, risk, microenterprise, export

ABSTRACT

The activities of microenterprises differs significantly from the operations of small, medium and large companies, because of the size of the business. Most microentrepreneurs are single entities in which the owner is responsible for all decisions, so he has to be an expert in every field of knowledge associated with the enterprise.

Risk is an inseparable part of the operation of any enterprise, also microenterprises, which is why it is very important for microenterprises to be aware of the risk to which it is exposed. This knowledge will enable them to make right decisions to protect themselves against the risk in an appropriate manner, thus avoiding losses. In the literature, there are many common ways of securing the risk in export available for the microenterprises. Their diversity allow to adjust the appropriate method to the type of the business.

This article helps answer the question of whether microenterprises are making an analysis of risk in their business, and what type of risks they believe are the most troublesome. It also cross-present various methods available on the market, as well as identify the most common methods used by microenterprises.
\end{abstract}

\section{Introduction}

Microenterprises are the entities that employ fewer than 10 employees and have an annual turnover not exceeding 2 million Euro or annual balance sheet total does not exceed 2 million Euro (Dz. Urz. UE L 187, 17.06.2014). According to this definition, microentrepreneurs operating on the Polish market in 2013 were $95.6 \%$ of all operating companies (www.stat.gov.pl, 14.01.2016). It should however be noted that the majority of all active 
microenterprises were single entities. This means that all the decisions, and therefore all knowledge, which is associated with entrepreneurship, rests on these individuals. Many times these people do not have such extensive knowledge and are guided by their own intuition. Lack of resources also prevents them from using the experts advices.

Despite the lack of funds and personnel, microentrepreneurs are strong group of entities, gaining competitive advantage thanks to their specific properties, which include:

- ability of quick respond on the changing business environment,

- opening business on innovation, which are more easily verified by the needs of the market,

- flexibility and speed decision allowing to use market opportunities,

- cost control by enterprises, as well as reducing them, allows them to be more competitive,

- more efficient flow of information inside the enterprise, than in larger entities, significantly streamline decision-making,

- the rate of organizing new places to work, which facilitate entering into cooperative agreements,

- responding to the specific needs of the local market.

Thanks to the above features microenterprises do well on the market and take significant share in the GDP. Unfortunately, every year many microenterprises are shutting down. Reasons of liquidation of the business are many, but the undeniable influence has, among others, the risks to which companies are exposed.

The risk exists in economic activity of every entrepreneur. Like most people, also most of the entrepreneurs noted the various risks that affect them. So they undertake activities to analyze the risk and to manage it. However, questions appears whether, despite of the obstacles, which are limited human and financial resources, microenterprises are managing risk or they work in an intuitive way, relying on their own experience and luck? The research described in this article are attempt to answer the question, which type of risk microenterprises are noticing in economic activity, as well as how they are managing it.

\section{Literature review}

In the literature there are many definitions of risk. T.H. Bednarczyk defines it as the possibility of occurrence of negative socio-economic phenomena (Bednarczyk, 2000). T.T. Kaczmarek defines it as the possibility of failure, and in particular the occurrence of events beyond the control of the acting subject, which he can not accurately predict and which can not fully prevent, and which - by reducing the useful results and/or by increasing expenditures - receive action entirely or partly attribute effectiveness and economic viability (Kaczmarek, 2005). Other definitions define risk as the possibility of circumstances, resulting in a loss or negative impact on property (Dudziński, Knap, 1999), as well as a combination of the likelihood of an event and its consequences (Atkins, Bates, 2008).

There are many risks of export activities, A. Bielawska distinguishes the following risks in foreign trade (Bielawska, 2006):

1. Individual risk - a result of contractors bad will or force majeure, which include:

a) the risk of counterparties - including difficulties in finding buyers for goods, discrepancy in quantity, quality or price of goods delivered from the earlier findings, delivery of goods in the wrong place, delayed, damaged or theft of stored items;

b) the credit risk - involving cash flow; 
c) the risk of contract - responsibility for manufactured products, conformity goods with the standards and safety regulations, and the proper use of the funds.

2. Market risk - refers to the existing situation and the development of social, technical and economic conditions in individual countries and can be considered as a general risk, economic risk and the risk of price changes on the financial market (Bielawska, 2006) Including:

a) the general risk - due to the diversity of socio-cultural and business framework conditions (eg.: language, mentality, rituals, culture, the tax system);

b) the economic risk - resulting from disparities in the economic development of countries;

c) the risk of changes in market prices - associated with changes in supply-demand relations, interest rates or exchange rates.

3. Country risk - occurs when a sovereign country does not want or can't meet its payment obligations. This risk can be divided into economic of the country (the reasons of default are economic) and political country (there is a danger that a foreign government suddenly breaks the agreement).

Numerous results of studies on the risk and lack of a universal definition of risk results in the lack of a coherent classification. Despite this, every company should analyze the risks faced by its activities and be able to manage it, because thanks to the right decisions and taking specific actions, the company can achieve an acceptable level of risk.

Among the many combinations of activities involving risk management process, on attention deserves a diagram presented in Figure 1.

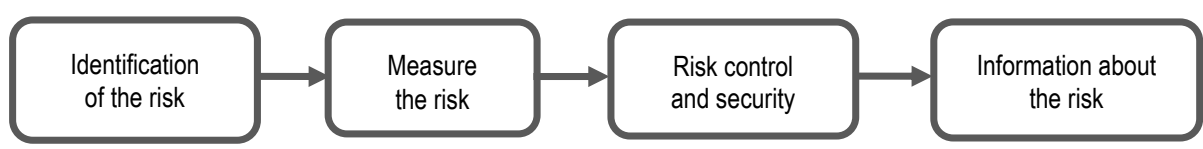

Figure 1. Steps of the enterprise risk management

Source: own work based on Tarczyński, Mojsiewicz (2001).

According to diagram, enterprise risk management starts with the identification of all the risks to which may be exposed enterprise. Then, using available methods and tools enterprise should measure all risks to introduce appropriate safeguards. The third step is to choose methods of security operations and risk control, and the last stage - current reported about the level of risk that was identified at the beginning.

In the literature authors presents many divisions of forms of risk security. One of them identifies three groups (Thoyts, 2010):

1. Avoiding risk - operate in a way that minimizes or completely eliminates possible risks.

2. Reduction risk - remedial action to reduce possibility of appearing the risk.

3. Transfer risk - the risk transfer to another entity that is willing to bear the risk in return for a fee.

Another division presents T.T. Kaczmarek, shows six groups:

- include risk in price of product or service,

- creating a reserve, 
- diversification of risk - by taking activities in different markets, producing different products or referral products for different consumer groups,

- transfer of risk - through commercial contract or insurance contract,

- compensation of risk - combination of transaction so that the risks associated with one transaction is the collateral for another.

Choosing the right option of risk management for microenterprises, is a much more difficult task, due to the lack of specialists in risk management. In large enterprises operate the office responsible for the export and risk management, while in microenterprises responsible for this rule is a person whose knowledge is often insufficient. (Williams Jr., Smith, Young, 2002) It should be noted, however, that the use of appropriate preventive methods by the microenterprises is dependent on the resources available for this purpose, and knowledge of managers. Risk management involves decision making and implementation of specific actions by the entity in order to achieve an acceptable level of risk. Businesses can therefore use different methods, which are widely available. (Jajuga, 2009) And the choice is very wide, including internal and external methods.

Internal methods include all the actions that enterprises can make by themselves. The most common forms of internal security can be divided into four groups:

1. Well-prepared commercial contract.

2. The use of modern systems and software. On the market there are a lot of companies offering systems and software for risk analysis activities, for example: Risk BPM offered by Blue Energy, E-business risk by SDPK, Comarch Asset Management by Comarch. Analyses carried out using a specially designed systems and software, enable the company to take an objective and fully informed decision, to reduce the risk. They do not replace people but help them. An important limitation is the price of such a system that is thousands of dollars.

3. Establishment of a specialized risk management units. The employee will affect the limitation of risks taken without the use of external assistance instruments and only by resource planning, for example: creating database of suppliers and buyers, invoicing sales to foreign customers in its own currency; using of leading or lagging; include risk in the price of goods or service; creating reserves.

4. Diversification of risk, involving entrance to the larger number of foreign markets, and as far as strengthening the position on them, systematically going out from unattractive markets and intensifying activities in profitable ones. Diversification can also mean diversity of the products themselves.

External security methods of risk means finding a way to transfer all or part of the risk to another business entity. Among the external forms of security risks most often highlighted are:

1. Insurance - a complex instrument that combines the elements of control, transfer, diversification, financing and risk retention (Michalski, 2000).

2. Hedging operations - involving the closure of open currency position by taking another position of the same size, but opposite to the hedged item (Misztal, 2004) Among them are four groups (Kudla, 2010):

- options - gives the holder the right to buy or sell a specific financial instrument at a certain price and time,

- a futures contract - a contractual agreement, generally made on the trading floor of a futures exchange, to buy or sell a particular commodity or financial instrument at a pre-determined price in the future, 
- swaps - financial instrument in which each of the two sides made on fixed dates in the future series of payments to the other party of the contract, at least one series of payments depends on the value base index (Jajuga, 2009),

- warrants - the right to purchase shares or securities at a fixed price in the future, and to subscribe to future issue of shares. It is a speculative instrument that can bring profits when the price of the underlying instrument will rise, but if it falls, then the entity will sustain losses. (Owsiak, 2002).

3. Bank guarantees - a guarantee from a lending institution ensuring that the liabilities of a debtor will be met.

4. Insurance guarantees - both parties enter into an agreement laying down the basic principles of cooperation relating to fees, duties, safeguards and possible claims (Michalik, Selig, 2001).

5. Instruments of payments - the documents necessary to fulfill the function of money non-cash means of payment, for example: letter of credit, forfaiting, factoring.

\section{Method}

The research were conducted using the CAWI method (Computer-Assisted Web Interview) among the two hundred and ten microenterprises in West Pomeranian Province. Entrepreneurs were asked four questions closed, and two closed question multiple choice. Answers to the questions allow to point the methods used by exporting microentrepreneurs. In the research took part the largest share of entrepreneurs running from two to five years $(63 \%)$, followed by young companies existing in the market for less than 2 years $(30 \%)$, while $7 \%$ were entities operating for more than 5 years.

\section{Resullts}

On the first question, concerning the perception of risk in business, all responders answered that such a risk perceive. None of the study subjects did not reply that its economic activity is risk-free.

Definitely worse response where given on the next question about the use of any method of analysis of the risks. Only $34 \%$ said that it needs to use different methods of risk analysis on which is exposed their business. The remaining $66 \%$ of the surveyed businesses responded that there is no need to make such an analysis in its operations.

Tahel 1. Type of risk that are the most troublesome in the opinion of microenterprises (\%)

\begin{tabular}{lc}
\hline \multicolumn{1}{c}{ Type of risk } & Percent of answers \\
\hline Mistakes in delivery & 12 \\
Ligidation of business partner & 15 \\
Delayed of debt repayment & 18 \\
Dishonest of business partner & 18 \\
Random events & 4 \\
Political decisions & 8 \\
Foreign exchange risk & 19 \\
Other & 6 \\
\hline
\end{tabular}

Source: own research. 
Despite not making risk analyzes by microentrepreneurs, each of them could indicate which risks are the most troublesome for their business. Foreign exchange risk was the most frequently reported by the surveyed entrepreneurs. Second in the order were dishonest of the business partner and the risk of delayed of debt repayment. While less frequently respondents pointed to the risk of random events and political risk.

All responses indicate a high awareness of microentrepreneurs, on the risks faced by their business. However, they have no knowledge or belief of the legitimacy of the risk analysis, and its usefulness in the business.

The surveyed population was asked about methods of security the transactions. Over $40 \%$ of the surveyed companies indicated that there is no need to use any security methods. The remaining entities replied what is presented in Figure 2.

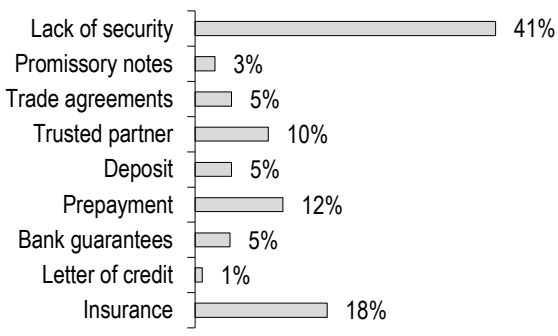

Figure 2. Methods of security of the transactions, used by surveyed population Source: own research.

Among the methods of securing the export activity, entrepreneurs most common pointed insurance $(18 \%)$. The second most common method was prepayment, which indicated $12 \%$ of the entities and concluding contracts with experienced and trusted partners (10\%). $5 \%$ of entrepreneurs in order to protect the business are using the deposit, bank guarantees and trade agreements. $3 \%$ of respondents pointed to external form of security risks which are promissory notes. A single entrepreneur point letters of credit.

\section{Limitations}

The survey was conducted among companies in Western Pomerania, so the test results may or may not necessarily represent the views of microentrepreneurs throughout the country.

\section{Conclusions}

Microentrepreneurs are the largest group of enterprises on the market, who know how to adapt to changes, but despite its flexibility and speed decision-making, many microentrepreneurs are closing the company's business activities.

Research shows that although all tested entities are aware of the existence of risks in their business, only every third entity makes its analysis. The variety of methods available on the market allows to respond to the needs of entrepreneurs, but education about the use of this methods is needed. Many entrepreneurs do not use any form of protection of their business, unaware of the risks faced by their economic activity. Education and promotion 
of knowledge about the risks and security methods can improve the situation and save many enterprises from liquidation.

It becomes important to raise awareness among microentrepreneurs of risk analysis, and importance of risk management. Useful in this would be campaigns aimed at this group of entrepreneurs, combined with the creation of special advisory points. A significant role in this play government, especially regional authority, that see the needs of the market in the region.

Risk analysis are also carried out multiple insurance companies, on the occasion of taking out an insurance policy by the microentrepreneur. Unfortunately, the level of insurance awareness among microentrepreneurs is very low. According to the report Qualifact „Finance SME 2013 - the market of insurance services”, only 73\% of microentrepreneurs has any insurance policy, not necessarily related to the economic activity. Consequently, only few microentrepreneurs are buying insurance. Education and promotion can improve this situation.

It is important to use the centers of transfer of knowledge and technology parks arising from universities, where the entrepreneurs can use from knowledge of scientists for free. An example is the Centre for Knowledge Transfer Service Inter-Lab, located at the Faculty of Economics and Management Services University of Szczecin. These are new solutions that have a chance to develop and to influence real change. The changes are indeed necessary. Ways of achieving them are many, and intensify all these activities will definitely bring a notable result, which will be greater awareness of the need for risk management among the entities.

\section{References}

Atkins, I. \& Bates, I. (2008). Insurance. London: Global Professional Publication.

Bednarczyk, T.H. (2000). Instrumenty wspierania eksportu. Kredyty i ubezpieczenia, Warszawa: Wydawnictwo Naukowe PWN.

Bielawska, A. (2006). Finanse zagraniczne MŚP Wybrane problemy. Warszawa: Wydawnictwo Naukowe PWN.

Dudziński, J. \& Knap, R. (1999). Handel zagraniczny. Szczecin: Wydawnictwo Zachodniopomorskiej Szkoły Biznesu w Szczecinie. Jajuga, K. (ed.) (2009). Zarządzanie ryzykiem. Warszawa: Wydawnictwo Naukowe PWN.

Kaczmarek, T.T. \& Zarzycki, M. (2005). Poradnik eksportera. Bydgoszcz-Warszawa: Oficyna Wydawnicza Branta.

Kudła, J. (2010). Instrumenty finansowe i ich zastosowania. Warszawa: Wydawnictwo Key Text.

Michalski, T. (2000). Rozdział 1. Ryzyko w działalności człowieka. In: J. Monkiewicz (red.), Podstawy ubezpieczeń tom I - mechanizmy i funkcje. Warszawa: Poltext.

Michalik, L. \& Seliga, D. (2001). Rozdział 8. Ubezpieczenia finansowe. In: J. Monkiewicz (red.), Podstawy ubezpieczeń: tom II - produkty. Warszawa: Poltext.

Misztal, P. (2004). Zabezpieczenie przed ryzykiem zmian kursu walutowego. Warszawa: Difin.

Owsiak, S. (2002). Podstawy nauki finansów. Warszawa: PWE.

Rejda, G.E. (2011). Principles of Risk Management and Insurance. Eleventh Edition. New Jersey: Pearson.

Tarczyński, W. \& Mojsiewicz, M. (2001). Zarządzanie ryzykiem. Podstawowe zagadnienia. Warszawa, PWE.

Thoyts, R. (2010). Insurance theory and practice. New York: Routledge.

Williams Jr., C.A., Smith, M.L. \& Young, P.C. (2002). Zarządzanie ryzykiem a ubezpieczenia. Warszawa: Wydawnictwo Naukowe PWN. www.stat.gov.pl (24.03.2015).

Attachment I to Commission regulation (EU) No 651/2014 of 17 June 2014 declaring certain categories of aid compatible with the internal market in application of Articles 107 and 108 of the Treaty.

Cite this article aS: Soroka-Potrzebna, H. (2016). Risk management according to the studies among exporting microenterprises from Western Pomerania. European Journal of Service Management, 20 (4), 41-47. DOI: 10.18276/ejsm.2016.20-05. 
